\title{
Yeast Upf1 CH domain interacts with Rps26 of the $40 S$ ribosomal subunit
}

\author{
EI EI MIN, ${ }^{1}$ BIJOYITA ROY, ${ }^{1}$ NADIA AMRANI, FENG HE, and ALLAN JACOBSON ${ }^{2}$ \\ Department of Microbiology and Physiological Systems, University of Massachusetts Medical School, Worcester, Massachusetts 01655, USA
}

\begin{abstract}
The central nonsense-mediated mRNA decay (NMD) regulator, Upf1, selectively targets nonsense-containing mRNAs for rapid degradation. In yeast, Upf1 preferentially associates with mRNAs that are NMD substrates, but the mechanism of its selective retention on these mRNAs has yet to be elucidated. Previously, we demonstrated that Upf1 associates with $40 \mathrm{~S}$ ribosomal subunits. Here, we define more precisely the nature of this association using conventional and affinity-based purification of ribosomal subunits, and a two-hybrid screen to identify Upf1-interacting ribosomal proteins. Upf1 coimmunoprecipitates specifically with epitope-tagged $40 \mathrm{~S}$ ribosomal subunits, and Upf1 association with high-salt washed or puromycin-released $40 \mathrm{~S}$ subunits was found to occur without simultaneous eRF1, eRF3, Upf2, or Upf3 association. Two-hybrid analyses and in vitro binding assays identified a specific interaction between Upf1 and Rps26. Using mutations in domains of UPF1 known to be crucial for its function, we found that Upf1:40S association is modulated by ATP, and Upf1:Rps26 interaction is dependent on the N-terminal Upf1 $\mathrm{CH}$ domain. The specific association of Upf1 with the 40S subunit is consistent with the notion that this RNA helicase not only triggers rapid decay of nonsense-containing mRNAs, but may also have an important role in dissociation of the premature termination complex.
\end{abstract}

Keywords: NMD; RNA helicase; ribosomal proteins

\section{INTRODUCTION}

Nonsense-mediated mRNA decay (NMD), a cytoplasmic mRNA surveillance pathway, targets transcripts harboring a premature translation termination codon (PTC) or a termination codon in a context characteristic of premature termination (Jacobson and Izaurralde 2007; Kervestin and Jacobson 2012; Kervestin et al. 2012). In part, NMD ensures that the potentially toxic polypeptide products of its substrate mRNAs do not accumulate in the cell (Jacobson and Izaurralde 2007; Kervestin and Jacobson 2012; Kervestin et al. 2012). Factors that regulate NMD include Upf1, Upf2, and Upf3, the principal regulators in all eukaryotes, as well as Smg-1 and Smg-5-9, proteins that play additional regulatory roles in metazoans (Kervestin and Jacobson 2012; Schoenberg and Maquat 2012). The three Upf proteins form a complex with Upf2 acting as a bridge between Upf1 and Upf3 (He et al. 1997; Serin et al. 2001; Chamieh et al. 2008). Single or multiple deletions of the UPF genes have similar mRNA decay phenotypes, suggesting that these proteins function in a common pathway ( $\mathrm{He}$ et al. 1997; Maderazo et al. 2000; Wang et al. 2001; He et al. 2003), albeit

${ }^{1}$ These authors contributed equally to this work.

${ }^{2}$ Corresponding author

E-mail allan.jacobson@umassmed.edu

Article published online ahead of print. Article and publication date are at http://www.rnajournal.org/cgi/doi/10.1261/rna.039396.113. one that may be branched under some circumstances (Chan et al. 2007; Huang et al. 2011).

Upf1, the key effector of NMD, has a cysteine- and histidine-rich zinc-finger domain ( $\mathrm{CH}$ domain) at its $\mathrm{N}$ terminus and a helicase domain comprised of 12 conserved motifs common to the members of helicase superfamily I (SF1) (Fairman-Williams et al. 2010). Upf1 shows RNA-dependent ATPase and 5'-to-3' RNA helicase activities, both of which, although critical for NMD (Czaplinski et al. 1998; Wang et al. 2001), have unresolved roles in the process. In yeast, ATPase-deficient Upf1 accumulates with NMD substrates in cytoplasmic processing bodies (Sheth and Parker 2006); and in human cells, ATPase- or helicase-deficient Upf1 leads to the accumulation of partially degraded $3^{\prime}$ decay intermediates (Franks et al. 2010). These reports and others (Ghosh et al. 2010) suggest a role for Upf1 in disassembling post-termination mRNPs in a mechanism that requires its ATPase and helicase activities. Notably, the maximal activation of these activities is stimulated by a complex of Upf2 and Upf3 (Chamieh et al. 2008; Chakrabarti et al. 2011).

Numerous studies have shown that NMD is inhibited by drugs, mutations, or mRNA structures that inhibit translation (Jacobson and Izaurralde 2007), or by suppressor tRNAs (Losson and Lacroute 1979; Gozalbo and Hohmann 1990; Belgrader et al. 1993), indicating that a premature stop codon must be recognized by translating ribosomes for NMD to 
occur. This conclusion is reinforced by experiments demonstrating a direct correlation between the extent of ribosome occupancy at a PTC and the degree to which NMD is activated (Gaba et al. 2005). Additional links between translation and NMD include the observations that decapping and degradation of nonsense-containing transcripts occur while the transcript is associated with polyribosomes (Mangus and Jacobson 1999; Hu et al. 2010) and that the Upf factors colocalize with polyribosomes, 80 S ribosomes, and ribosomal subunits (Peltz et al. 1993; Atkin et al. 1995, 1997; Mangus and Jacobson 1999; Ghosh et al. 2010). Consistent with a dependence of NMD on translation termination, Upf1 interacts with the release factors eRF1 and eRF3 in humans and yeast, possibly to function in termination events using its helicase and RNA binding activities (Czaplinski et al. 1998; Wang et al. 2001; Ghosh et al. 2010). In vertebrates, Upf1 and its regulator Smg-1 interact with the release factors forming the SURF (Smg-1-Upf1-Release factors) complex, and this SURF-associated Upf1 appears to be able to interact with Upf2-Upf3 bound to the exon junction complex (Yamashita et al. 2009; Kashima et al. 2010).

Although nonsense codon recognition by the ribosome and Upf1 interaction with the release factors are steps that are incorporated into most models of NMD (Kervestin and Jacobson 2012), there is some uncertainty about the timing and specificity of Upf1 interaction with terminating mRNPs. Some models and some experimental results indicate that mechanistic distinctions between premature and normal termination lead to preferential association of Upf1 with mRNPs undergoing premature termination (Amrani et al. 2004, 2006; Bühler et al. 2006; Johansson et al. 2007; Kervestin and Jacobson 2012; Kervestin et al. 2012). Other models and other data suggest that Upf1 associates with all terminating ribosomes, and specificity for premature termination events is achieved by subsequent Upf1 interactions with factors that could only remain mRNA-associated if termination had occurred upstream of its normal site (Peltz et al. 1993; Le Hir et al. 2000; Sun and Maquat 2000). Additional studies imply that specificity for hUpf1 is imparted by mRNA 3'-UTR length (Hogg and Goff 2010). Here, we address the Upf1 localization problem by providing biochemical and genetic evidence for the association of Upf1 with ribosomal subunits in the budding yeast Saccharomyces cerevisiae. First, we utilized independent approaches to confirm our earlier observations of Upf1 association with the $40 \mathrm{~S}$ ribosomal subunit (Ghosh et al. 2010). Having confirmed such interactions, we then defined the domains of Upf1 on which they depend as well as a specific ribosomal protein with which Upf1 interacts.

\section{RESULTS}

\section{Upf1 binds to affinity-purified 40S ribosomal subunits}

Our previous experiments demonstrated that yeast Upf1 associates with purified $40 \mathrm{~S}$ ribosomal subunits (Ghosh et al.
2010). We have now explored this interaction further by testing whether Upf1 is retained by an alternative method of ribosome isolation, namely affinity purification. We constructed yeast strains harboring epitope-tagged Rps13 or Rpl25 (Table 1), which would be incorporated into $40 \mathrm{~S}$ or $60 \mathrm{~S}$ ribosomal subunits, respectively. These proteins were selected for modification based on their accessibility on the solvent side of the ribosome (Spahn et al. 2001; Inada et al. 2002; Ben-Shem et al. 2011). We inserted a hemagglutinin (HA) tag at the $\mathrm{C}$ terminus of Rps 13 and a c-Myc tag at the $\mathrm{C}$ terminus of Rpl25. The tags did not appear to disrupt the functions of the respective proteins since the tagged strains exhibited growth characteristics comparable to those of untagged strains in liquid yeast extract peptone dextrose (YEPD) culture at $25^{\circ} \mathrm{C}$ (Fig. 1A) or on multiple solid media at $25^{\circ} \mathrm{C}$ or $30^{\circ} \mathrm{C}$ (Fig. $1 \mathrm{~B}$ ). Immunoprecipitations with antibodies targeting the HA or c-Myc epitopes showed efficient capture of the corresponding ribosomal protein from cell extracts (Fig. $2 \mathrm{~A}, \mathrm{~B}, \mathrm{cf}$. lane 5 in top panels). Importantly, we found Upf1 to be present in these immunoprecipitates but absent in immunoprecipitates from untagged strains (Fig. 2A,B, bottom panels, cf. lane 5 to lane 2). These results demonstrate that Upf1 is also associated with a ribosomal complex using extraction conditions that differ from those used in our original experiments (Ghosh et al. 2010). Cell-free extracts treated with puromycin to promote ribosome dissociation (Lawford 1969; Azzam and Algranati 1973; Algire et al. 2002) allowed for a test of the subunit-specific association of Upf1 (Fig. 2A,B). Under these conditions, we observed significant enrichment of Upf1 in the HA-specific immunoprecipitates (targeting Rps13-HA) (Fig. 2A, bottom panel, lane 8)

TABLE 1. Yeast strains used in this study

\begin{tabular}{|c|c|c|}
\hline Strains & Genotype & Reference \\
\hline MBS & $\begin{array}{l}\text { MATa ade2-1 his3-11,15 leu2-3,112 } \\
\text { trp1-1 ura3-1 can1-100 [rho+] } \\
\text { L-o, M-o }\end{array}$ & $\begin{array}{l}\text { Amrani et al. } \\
2004\end{array}$ \\
\hline NAY101 & $\begin{array}{l}\text { MATa ade2-1 his3-11,15 leu2-3,112 } \\
\text { trp1-1 ura3-1 can1-100 [rho+] } \\
\text { L-o, M-o, upf1 :: HIS3 }\end{array}$ & $\begin{array}{l}\text { Amrani et al. } \\
2004\end{array}$ \\
\hline NAY215 & $\begin{array}{l}\text { MATa ade2-1 his3-11,15 leu2-3,112 } \\
\text { trp1-1 ura3-1 can1-100 [rho+] } \\
\text { L-o, M-o, RPL25-c-MYC }\end{array}$ & This study \\
\hline NAY217 & $\begin{array}{l}\text { MATa ade2-1 his3-11,15 leu2-3,112 } \\
\text { trp1-1 ura3-1 can1-100 [rho+] } \\
\text { L-o, M-o, upf1 :: HIS3, RPL25- } \\
\text { c-MYC }\end{array}$ & This study \\
\hline NAY223 & $\begin{array}{l}\text { MATa ade2-1 his3-11,15 leu2-3,112 } \\
\text { trp1-1 ura3-1 can1-100 [rho+] } \\
\text { L-o, M-o, RPS13-HA }\end{array}$ & This study \\
\hline NAY225 & $\begin{array}{l}\text { MATa ade2-1 his3-11,15 leu2-3,112 } \\
\text { trp1-1 ura3-1 can1-100 [rho+] } \\
\text { L-o, M-o, upf1 :: HIS3, RPS13-HA }\end{array}$ & This study \\
\hline GGY1::171 & $\begin{array}{l}\text { gal4A gal80A URA3::GAL1-lacZ his3 } \\
\quad \text { leu2 }\end{array}$ & $\begin{array}{c}\text { He et al. } \\
1996\end{array}$ \\
\hline
\end{tabular}




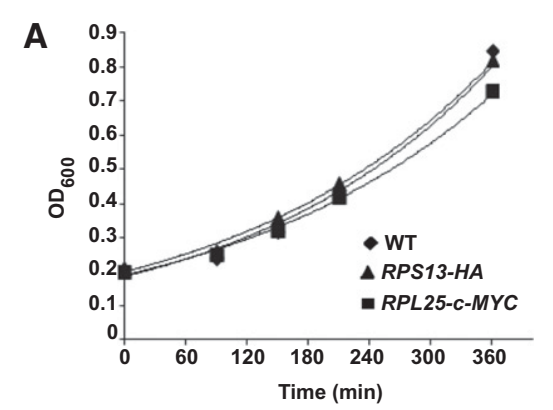

B

\begin{tabular}{ll|l|l|l}
\hline Growth conditions & WT & RPS13-HA & RPL25-C-MYC \\
\hline YEPD & $25^{\circ} \mathrm{C}$ & & & \\
YEPD & $30^{\circ} \mathrm{C}$ & & 00 & \\
G418 & $25^{\circ} \mathrm{C}$ & & & 00 \\
G418 & $30^{\circ} \mathrm{C}$ & & $\ddots \% 00$ & 00 \\
\hline
\end{tabular}

FIGURE 1. Yeast strains harboring HA- or c-Myc-tagged RPS13 or RPL25 genes grow at wild-type (WT) rates. (A) Growth curves for yeast strains in liquid YEPD medium at $25^{\circ} \mathrm{C}$. ( ) WT; (ム) RPS13-HA; (-) RPL25-c-Myc. (B) Liquid cultures of yeast strains WT, RPS13-HA, and $R P L 25-c-M y c$ were serially diluted and incubated on YEPD plates and plates containing G418 at the temperatures shown.

but not in the c-Myc-specific immunoprecipitates (targeting Rpl25-c-Myc) (Fig. 2B, bottom panel, lane 8). These results demonstrate that, in an independent assay, Upf1 still associates with $40 \mathrm{~S}$ ribosomal subunits and not with $60 \mathrm{~S}$ subunits. To determine whether this association was mediated indirectly by Upf1 interaction with mRNA, cell lysates were treated with micrococcal nuclease prior to ribosome immunoprecipitation. These experiments showed significant retention of Upf1 in the immunoprecipitates (Fig. 2C, lane 6), implying that Upf1 is associated directly with ribosomes. The absence of poly(A)-binding protein (Pab1), a factor known to be associated with the mRNA 3' poly(A) tail (Sachs and Davis 1989), in the immunoprecipitates further supported the idea that Upf1 is associated with ribosomes.

\section{Upf1 association with 405 ribosomal subunits requires its ATPase activity, but not its ATP-binding or RNA-binding activities, or the functions of the other NMD factors}

To further understand the basis of Upf1 association with $40 \mathrm{~S}$ ribosomal subunits, we employed domain-specific mutations to determine whether some of the biochemical activities known to be associated with those Upf1 domains might be required for this interaction. High-salt washed $40 \mathrm{~S}$ and $60 \mathrm{~S}$ ribosomal subunits were purified with or without prior puromycin release from cells harboring wild-type UPF1, or different $u p f 1$ alleles (Fig. 3A), and tested for Upf1:40S association by western blotting. The concurrent retention of Rps6 in the purified ribosomal subunits served as a control for $40 \mathrm{~S}$ subunit integrity and $60 \mathrm{~S}$ subunit purification. As shown in Figure 3B, neither the $\mathrm{C} 62 \mathrm{Y}$ or $\mathrm{C} 84 \mathrm{~S}$ mutations in the N-terminal $\mathrm{CH}$ domain nor the K436E or RR973AA mutations in the C-terminal helicase domain (that respectively inactivate ATP binding or RNA binding) had any significant effect on the association of Upf1 with high-salt washed 40S subunits prepared with or without puromycin-mediated release. In contrast, Upf1 derived from the upf1 DE572AA ATP hydrolysis mutant failed to associate to any significant extent with $40 S$ subunits even though Rps6 was amply recovered and Upf1 from the DE572AA mutant was expressed at levels comparable to wild-type Upf1 (Fig. 3C). Wild-type Upf1, analyzed in the same manner as the five mutant versions of the protein, retained its preference for $40 \mathrm{~S}$ subunit association (Fig. 3B).

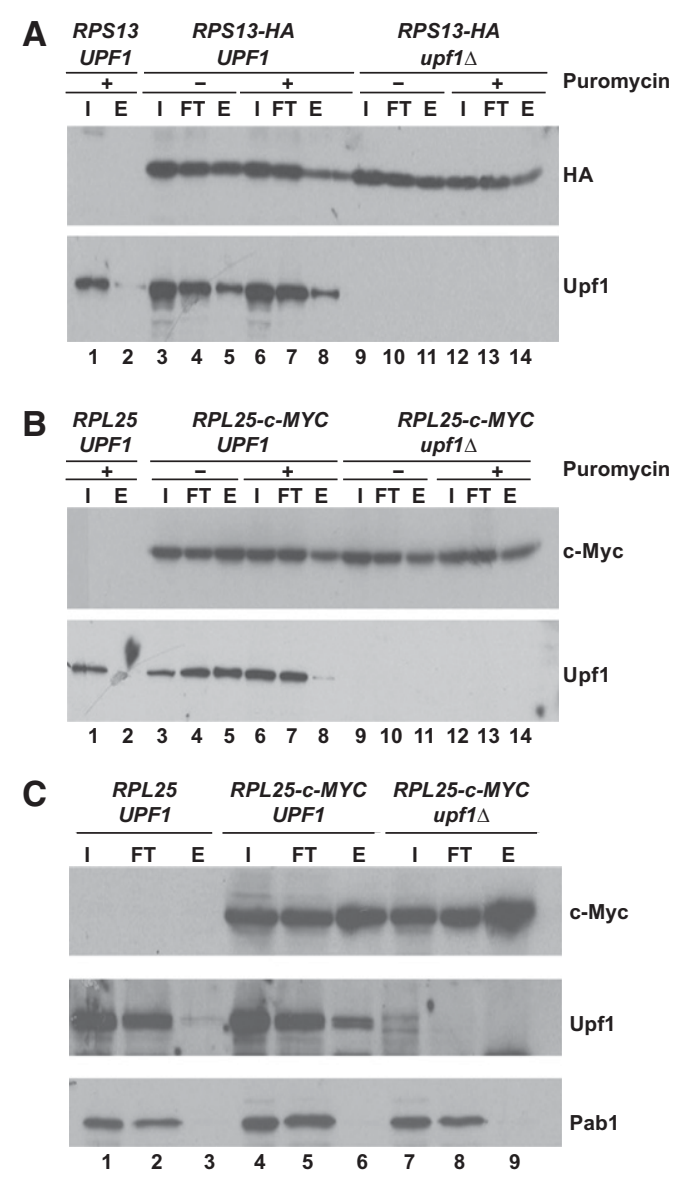

FIGURE 2. Treatment with puromycin diminishes coimmunoprecipitation of Upf1 with Rpl25-c-Myc, but not with Rps13-HA. Lysates from WT, RPS13-HA-WT, and RPS13-HA-upf1 $\triangle$ cells (A), and WT, RPL25-cMYC-WT, and RPL25-c-MYC-upf1 $\triangle$ cells (B) prepared with (+) or without (-) puromycin treatment were immunoprecipitated with anti-HA antibody or anti-c-Myc antibody, respectively. $(C)$ Micrococcal nuclease-treated lysates from WT, RPL25-c-MYC-WT, and RPL25-c$M Y C-u p f 1 \Delta$ cells were immunoprecipitated with anti-c-Myc antibodies. Input (I), flowthrough (FT), and eluate (E) were analyzed by western blotting for the presence of Rps13-HA, Rpl25-c-Myc, Upf1, or Pab1 with specific antibodies. 


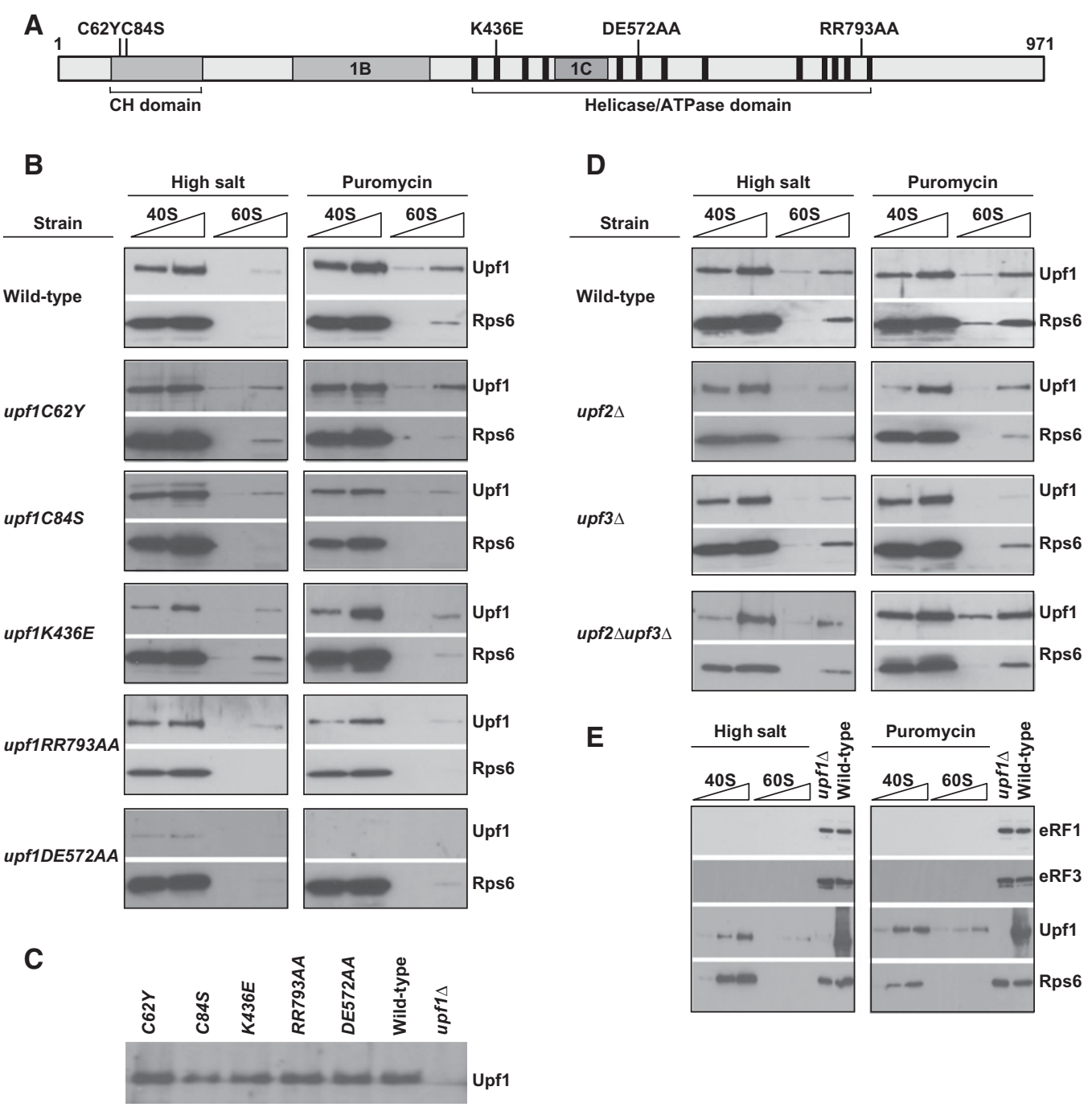

FIGURE 3. Upf1:40S ribosomal subunit association is modulated by ATP and is independent of Upf2, Upf3, or translation termination release factors eRF1/Sup45 and eRF3/Sup35. (A) Schematic representation of amino acid substitutions in the functional domains of Upf1. ( $B, D, E)$ Ribosomal subunits were prepared under high-salt conditions with or without prior puromycin treatment from yeast strains of the indicated genotypes. Increasing amounts $(5 \mu \mathrm{g}$ and $10 \mu \mathrm{g})$ of purified subunits were analyzed by SDS-PAGE and western blots were probed with specific antibodies; $(B)$ strains harboring different $u p f 1$ alleles; $(D)$ strains harboring $u p f 2 \Delta$, upf3 3 , or $u p f 2 \Delta u p f 3 \Delta$ mutations, and $(E)$ wild-type cells. In $E$, lanes marked $u p f 1 \Delta$ or wildtype are lysates from the respective cells. $(C)$ Western blot for Upfl from equal amounts of cell lysates of the indicated genotypes.

Additional insight into the determinants of Upf1 association with $40 \mathrm{~S}$ subunits was obtained by evaluating whether the other two Upf proteins were required for this association. High-salt washed $40 \mathrm{~S}$ and $60 \mathrm{~S}$ ribosomal subunits were purified with or without prior puromycin treatment from cells lacking Upf2, Upf3, or both proteins, and then assayed by western blotting for retention of Upf1 (Fig. 3D). These experiments showed that Upf1 copurified predominantly with $40 \mathrm{~S}$ ribosomal subunits in $u p f 2 \Delta$, upf $3 \Delta$, and $u p f 2 \Delta u p f 3 \Delta$ strains, similar to the results observed in wild-type strains and consistent with earlier studies showing that polysome-association of Upf1 is independent of the other NMD factors (Atkin et al. 1997). In several of the strains analyzed, a modest amount of Upf1 association with 60S subunits was observed; however, as monitored by Rps6 recovery, this appeared to re- flect $40 \mathrm{~S}$ subunit contamination in the $60 \mathrm{~S}$ subunit preparations (Fig. 3D). Collectively, these data indicate that the association of Upf1 with 40S ribosomal subunits is neither bridged by nor dependent on Upf2 or Upf3.

Several reports of experiments done in yeast and mammalian cells have indicated that Upf1 association with a prematurely terminating ribosome may be attributable to direct interactions with the release factors, eRF1 and eRF3 (Czaplinski et al. 1998; Kashima et al. 2006; Ivanov et al. 2008; Singh et al. 2008). Since we observed Upf1 association with $40 \mathrm{~S}$ subunits purified after puromycin release (Fig. 3C,D), it seemed unlikely that maintenance of Upf1:40S interaction depended on the eRFs. Nevertheless, we tested directly whether either of the release factors was present in the purified $40 \mathrm{~S}$ ribosomal subunits. Western blotting analyses 
showed that the same subunit preparations that had substantial bound Upf1 were devoid of detectable levels of Sup45/ eRF1 or Sup35/eRF3 (Fig. 3E), indicating that Upf1 can maintain an association with $40 \mathrm{~S}$ ribosomal subunits independent of the two release factors. However, whether Upfl's initial association with the $40 \mathrm{~S}$ subunits depended on these factors remains to be ascertained.

\section{Upf1 interacts with $40 S$ ribosomal proteins}

Upf1 association with $40 \mathrm{~S}$ ribosomal subunits suggests two possible types of interactions that may mediate this association: protein-protein and/or protein-rRNA. Evidence for Upf1:ribosomal protein association has been obtained from coimmunoprecipitation experiments in higher eukaryotes (Yamashita et al. 2009). This precedent, and our observation that Upfl's RNA-binding activity was dispensable for $40 \mathrm{~S}$ subunit association (Fig. 3B), led us to test for Upf1 interaction with specific small subunit ribosomal proteins using a directed yeast two-hybrid screen. Using full-length Upf1 as bait (fused to the GAL4 DNA binding domain) and thirty-two 40S ribosomal proteins as prey (fused to the GAL4 activation domain) (He et al. 1996; Valášek et al. 2003), bait and prey plasmids were cotransformed into a S. cerevisiae GGY1::171 strain that contains an integrated GAL1-lacZ reporter construct. In these strains, the expression of the reporter is directly related to the extent of interaction of the bait and prey proteins. With a GAL4-UPF2 fusion serving as a positive control for two-hybrid interaction, five ribosomal proteins were found to manifest significant lac $Z$ expression, indicating an interaction with Upf1 (Fig. 4, left panel). In both qualita-

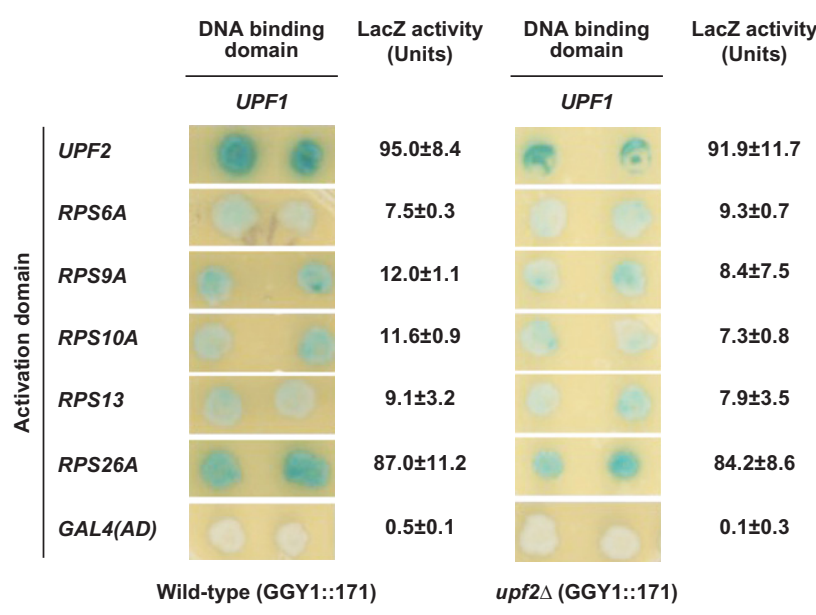

FIGURE 4. Upf1 interacts with $40 \mathrm{~S}$ ribosomal proteins. Directed yeast two-hybrid assays were performed using UPF1-GAL4 (DNA-binding domain) as bait and a library of RPS-GAL4 (activation domain) fusion proteins as prey. Individual transformants were assayed for $\beta$-galatosidase activity qualitatively on plates and quantitatively in liquid assays. Interactions were tested in GGY1::171 wild-type (left) and GGY1::171 upf2 $2 \Delta$ (right) strains. Values for $\beta$-galatosidase assays represent mean \pm standard deviation for three independent experiments performed on cultures from independent transformants. tive plate-based and quantitative liquid $\beta$-galactosidase assays, the strongest interactions were observed with Rps26. Significantly, the Upf1:Rps26 interaction was as strong qualitatively and quantitatively as the well-characterized Upf1: Upf2 interaction (Fig. 4, left panel; He and Jacobson 1995; He et al. 1996). Weaker Upf1 interactions were observed with Rps6, Rps9, Rps10, and Rps13 (Fig. 4, left panel).

Although our experiments with purified subunits show that Upf1 association with the 40S subunit is independent of Upf2 and Upf3, we tested if the two-hybrid interactions with the individual ribosomal proteins were mediated by either of these NMD factors or by some aspect of Upf1 multimerization. We assayed the interactions between Upf1 and the candidate ribosomal proteins in two-hybrid yeast strains harboring deletions of UPF1, UPF2, or UPF3 and found no change in the interactions between Upf1 and the candidate ribosomal proteins in any of these strains (Fig. 4, right panel, and data not shown). These results indicate that Upf1:40S ribosomal protein interactions are not bridged by other NMD factors and are likely to be direct.

\section{Point mutations in the $\mathrm{CH}$ domain of Upf1 alter its interaction with Rps26}

To gain further insight into the Upf1 domain that interacts with Rps26, its strongest 40S ribosomal protein interactor, we analyzed Upf1:Rps26 interaction using five full-length upf1 loss-of-function alleles (Fig. 3A). Figure 5B shows that two-hybrid interaction between Upf1 and Rps26 was lost completely in strains harboring the $\mathrm{C} 62 \mathrm{Y}$ or $\mathrm{C} 84 \mathrm{~S}$ mutations. The K436E mutation showed a modest decrease in lacZ expression, whereas the DE572AA and RR793AA mutants did not exhibit any change in two-hybrid interaction. The loss of interaction with Rps26 in the $\mathrm{C} 62 \mathrm{Y}$ or $\mathrm{C} 84 \mathrm{~S}$ alleles suggests that Upf1's N terminus mediates interaction with Rps26. The domain encompassing the K436E mutation in hUpf1 has been demonstrated to form a rigid association with the $\mathrm{CH}$ domain (Clerici et al. 2009), which could explain the partial loss of interaction in the K436E mutation. Interestingly, neither the $\mathrm{C} 62 \mathrm{Y}$ nor the $\mathrm{C} 84 \mathrm{~S}$ mutations affect the association of Upf1 with polysomes or 40S ribosomal subunits (Fig. 3B; Atkin et al. 1997; S Ghosh and A Jacobson, unpubl.), suggesting that Upf1:40S association may be a multivalent interaction involving multiple interacting epitopes.

\section{Upf1 $\mathrm{N}$ terminus is required for its interaction with Rps26}

Mutations in the Upf1 $\mathrm{N}$ terminus completely disrupted its interaction with Rps26 (Fig. 5B). However, the ability of two different Upf1 proteins with C-terminal amino acid substitutions (DE572AA or RR793AA) to retain interaction with Rps26 does not rule out the possibility that the Upf1 C terminus also interacts with Rps26. To define more precisely the domain(s) of Upf1 that mediate interaction with Rps26, we 


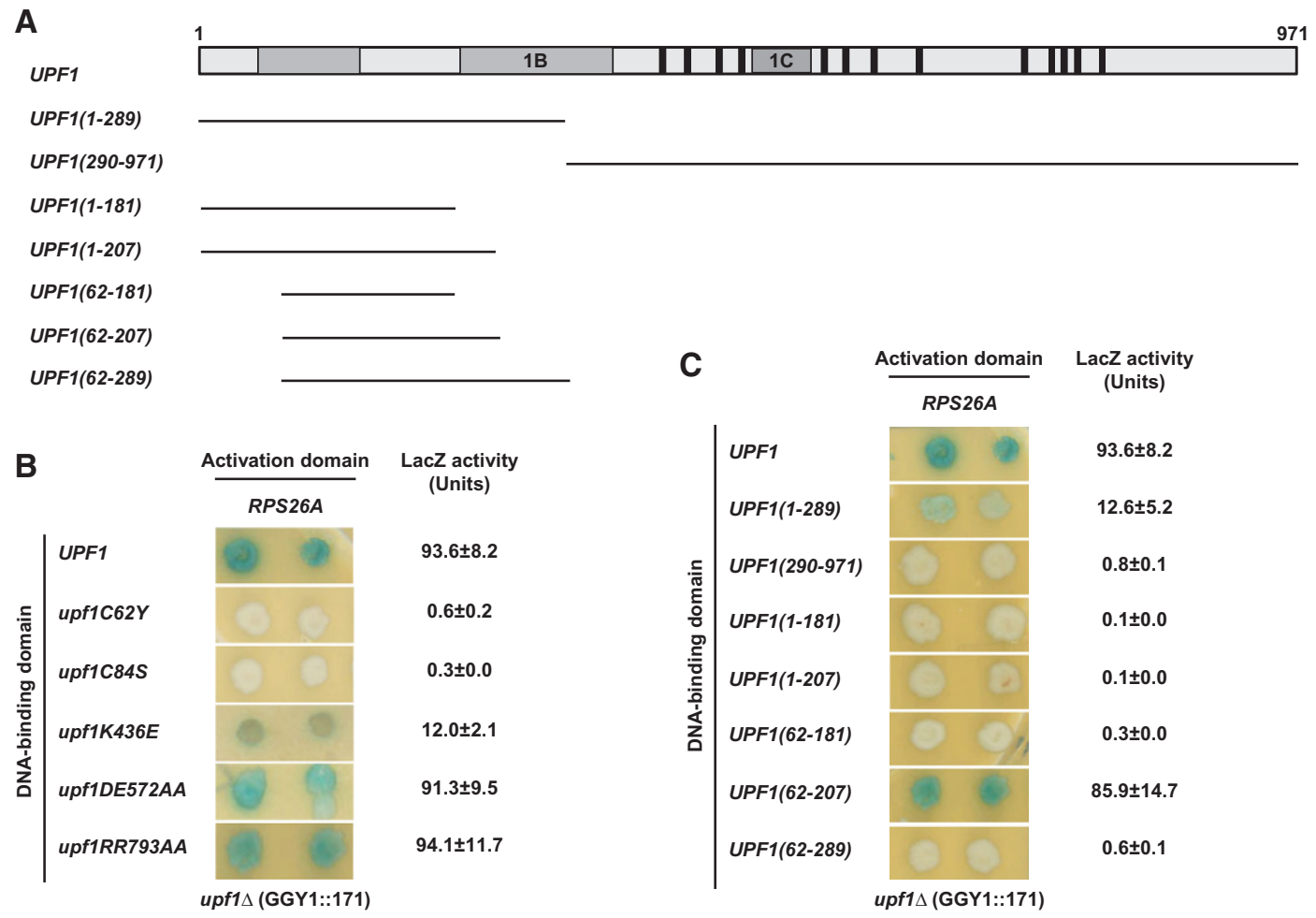

FIGURE 5. The CH domain of Upf1 mediates interaction with Rps26. (A) Schematic representation of Upf1 fragments tested for interaction with Rps26. $(B, C)$ Two-hybrid assays were performed in the GGY1::171 upf1 strain to prevent any effects of possible oligomerization with endogenous Upf1 protein. Interaction of Rps26 with either full-length Upf1 mutant alleles $(B)$ or indicated truncations of Upf1 $(C)$ are shown. Values for $\beta$-galatosidase assays represent mean \pm standard deviation for three independent experiments performed on cultures from independent transformants.

further tested the interactions of a series of previously characterized N- and C-terminal Upf1 truncations (Fig. 5A; He et al. 1997). We first tested Upf1(1-289), which harbors only the first 289 amino acid residues of Upf1, and Upf1 (290-971), which lacks the first 289 amino acids of Upf1. Upf1(1-289), which includes the $\mathrm{CH}$ domain but lacks the helicase domains of Upf1, still showed interaction with Rps26 (Fig. 5C). Upf1(290-971), on the other hand, failed to show any interaction with Rps26 (Fig. 5C), confirming that the C-terminal domains of Upf1 are not important for binding to Rps26. To further narrow down the minimal interaction domain on Upf1, we tested $\mathrm{N}$ - and C-terminal truncations of the Upf1(1-289) fragment. Since residues 62 and 84 were found to be important for Rps 26 interaction (Fig. 5B), fragments tested spanned residues 1-181, 1-207, 62-181, 62-207, and 62-289 (Fig. 5A). The shortest Upf1 fragment that still retained the ability to interact with Rps26 was comprised of residues 62-207 (Fig. 5C). Interestingly, the interaction of Upf1(1-289) with Rps26 was weaker than that observed with either full-length Upf1, or the shortest Upf1(62-207) fragment.

\section{Rps26 interacts with Upf1 in vitro}

Two-hybrid interactions can be bridged (Bartel et al. 1993; Bartel and Fields 1995; He et al. 1997), so we sought to deter- mine whether Upf1:Rps26 interaction could be confirmed biochemically, using an in vitro binding assay. Purified yeast FLAG-Upf1 (Fig. 6A) and lysates from Escherichia coli expressing recombinant His-tagged Rps26 (Fig. 6B) were incubated and subjected to immunoprecipitation using antiFLAG beads. An E. coli strain not expressing any His-tagged protein was used as a control for background binding. Analysis of the immunoprecipitates showed coimmunoprecipitation of His-Rps26 with FLAG-Upf1 and not with FLAG beads alone (Fig. 6C, cf. lanes 8 and 12). This in vitro data, in addition to the two-hybrid analyses, demonstrates that Upf1 association with the $40 \mathrm{~S}$ subunit is mediated at least in part by a direct interaction with $40 \mathrm{~S}$ ribosomal protein Rps 26 and does not involve any endogenous yeast protein bridging the interaction.

\section{DISCUSSION}

Upf1 plays a central role in triggering NMD as well as in promoting several processes ancillary to this quality control pathway, including translational repression, dissociation of the translating mRNP, degradation of the nascent polypeptide, and inhibition of pre-mRNA splicing (Kervestin and Jacobson 2012). Accordingly, the platform from which Upf1 launches these diverse activities is of considerable interest. Notwithstanding disagreement about the involvement of 


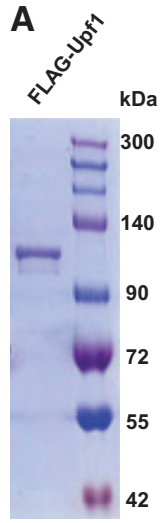

B

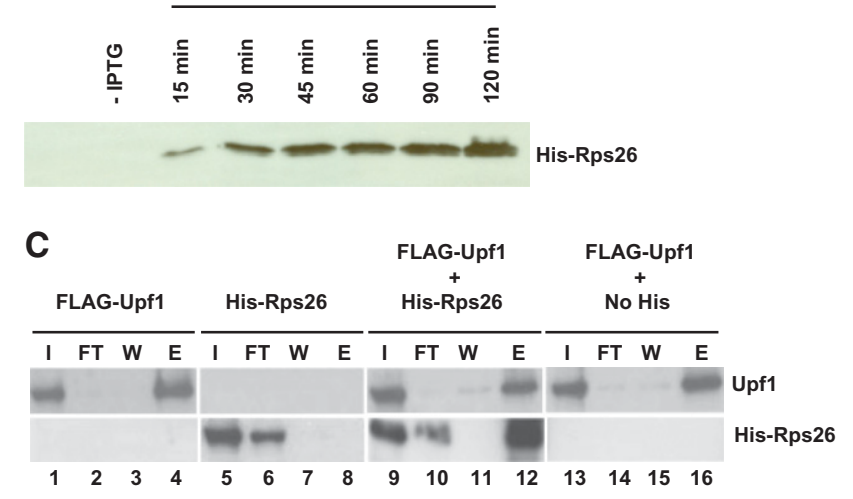

FIGURE 6. Upf1 interacts with Rps26 in vitro. In vitro binding assays were performed with $E$. coli BL21(DE3) cells expressing His-Rps26. (A) Coomassie-stained SDS-PAGE gel showing purity of yeast FLAG-Upf1. (B) Time course of His-Rps26 expression after IPTG induction in E. coli BL21 (DE3) cells. (C) Western blot analyses of anti-FLAG immunoprecipitation assays utilized anti-His and anti-Upf1 antibodies on input (I), flowthrough (FT), wash (W), and eluate (E) fractions.

as a strong interacting partner of Upf1 (Figs. 4, 6). The interaction between Upf1 and Rps26 was observed to be specific, direct, and independent of the other Upf factors (Figs. 4, 6). Consistent with the latter result, the association of Upf1 with purified subunits was also found to be independent of Upf2 and/or Upf3 (Fig. 3D). Two-hybrid analyses that exploited different upf1 alleles showed that the RR793AA RNA-binding mutant had no effect on Upf1:Rps26 interaction, whereas single point mutations in the $\mathrm{CH}$ domain abrogated the ability of Upf1 to interact with Rps26 completely (Fig. $5 \mathrm{~B})$. The requirement for a functional Upf1 N-terminal $\mathrm{CH}$ domain in Upf1: Rps26 interaction was further evident from deletion analyses which showed

all termination events or just those which are premature, several models suggest that an early event in NMD is the interaction of Upf1 with the release factors localized at the A site of a terminating ribosome (Kervestin and Jacobson 2012). The implication of such models is that Upf1, and perhaps the other Upfs, should be associated with ribosomes during at least one phase of their functional lifetimes. This notion was supported by early experiments demonstrating polysomal localization of the Upfs (Peltz et al. 1993; Atkin et al. 1995, 1997), as well as by more recent studies which have localized Upf1 to the SURF complex (Yamashita et al. 2009) or to purified 40S ribosomal subunits (Ghosh et al. 2010). To understand the mechanistic basis for Upfl's association with the termination complex, we have pursued details of its mode of interaction with yeast ribosomes.

Using affinity purification of tagged ribosomal subunits, we demonstrate here that Upf1 is specifically immunoprecipitated with tagged $40 \mathrm{~S}$ ribosomal subunits and not $60 \mathrm{~S}$ subunits (Fig. 2), consistent with our previous results (Ghosh et al. 2010). The significant enrichment of Upf1 in ribosomal pulldowns of micrococcal nuclease-treated lysates, as well as the failure to detect poly(A)-binding protein (Pab1) in these pulldowns, indicates that ribosome association of Upf1 is likely mediated by a direct interaction with the $40 \mathrm{~S}$ subunit and not through residual ribosome-associated mRNA. Importantly, this conclusion is reinforced by the observation that the association of Upf1 with the 40S ribosome is sufficiently stable to resist either high salt-induced or puromycin-triggered ribosomal dissociation (Fig. 3). Stable association of Upf1 with the $40 \mathrm{~S}$ subunit appears to be modulated by ATP, and independent of the simultaneous presence of Upf2 or Upf3, or translation termination factors eRF1 and eRF3 (Fig. 3).

The demonstration of specific Upf1 association with the $40 \mathrm{~S}$ subunit led us to screen for Upf1:40S ribosomal protein interactions, an experimental approach that identified Rps 26 that only those Upf1 fragments containing the $\mathrm{CH}$ domain could interact with Rps26 (Fig. 5C). Interestingly, although the $\mathrm{C} 62 \mathrm{Y}$ and $\mathrm{C} 84 \mathrm{~S}$ mutation in the $\mathrm{CH}$ domain of Upf1 abolished the Upf1:Rps26 interaction, these mutations did not significantly affect Upfl's association with the 40S ribosomal subunit. This observation suggests that Upf1 ribosomal association is likely mediated through multiple interaction epitopes. In support of this idea, we found Upf1 also interacts with Rps6, Rps9, Rps10, and Rps13 (Fig. 4).

The K436E mutation in the UPF1 ATP-binding domain also manifested impaired Upf1:Rps26 interaction, although not to the extent seen with the $\mathrm{CH}$ domain mutants (Fig. 5B). X-ray crystallographic analysis of hUpf1 has demonstrated a strong association between the $\mathrm{CH}$ domain (encompassing residues C62 and C84) and domain 1A (encompassing residues K436 and DE572), suggesting that Upf1 may adopt a folded conformation that allows these domains to not only interact with each other, but with Rps 26 as well. Interestingly, we noted that the interaction between the DE752AA ATP hydrolysis mutant of Upf1 with Rps26 was not affected in the two-hybrid assay, whereas association of this mutant protein with the purified 40S subunits was lost (Fig. 3B). The lack of complete correspondence between the mutations that affect two-hybrid interaction and copurification with $40 \mathrm{~S}$ subunits must take into account the differences between the two assays. Although copurification demands stable association with the subunit subsequent to treatment with high salt or puromycin, the two-hybrid assay is capable of registering a transient binding event that may be a precursor, for example, to the post-puromycin state. The former may have a readily detectable two-hybrid interaction (e.g., Rps26), whereas the latter may not. The DE572AA mutation may trap Upf1 in a conformation or state during its function that can bind to mRNA but not to the 40S ribosomal subunit. The possibility that Upf1 association with a translating mRNP involves complex mechanisms has been 


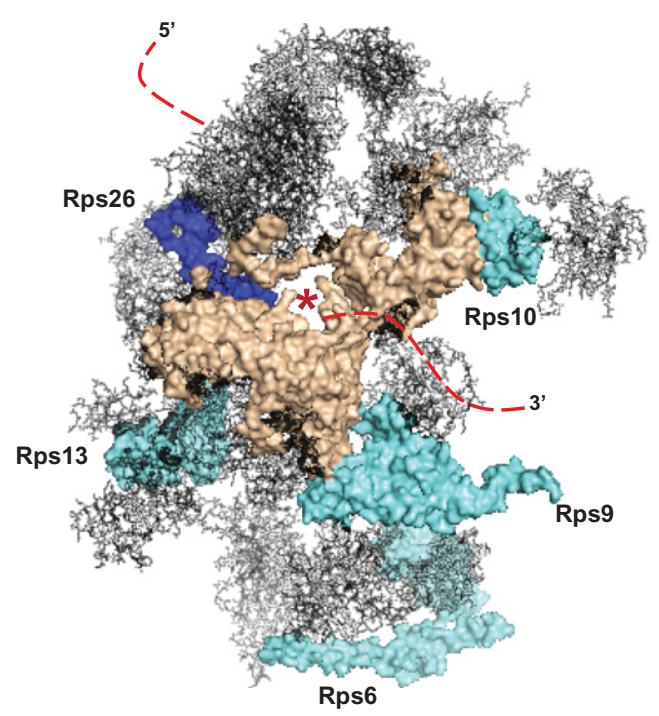

FIGURE 7. Upf1-interacting ribosomal proteins and eIF3 binding site on the solvent side of the $S$. cerevisiae $40 \mathrm{~S}$ subunit. The image showing ribosomal proteins only was created using PyMol (http://www.pymol. org) and is based on a Protein Data Bank entry (accession number 3U5C) (Ben-Shem et al. 2011). Ribosomal proteins interacting with Upf1 are highlighted using different shades of blue (dark blue denoting strong interaction and light blue representing weak interaction in the two-hybrid assay). The eIF3 binding site is highlighted in tan (Kouba et al. 2012). The asterisk denotes the mRNA entry channel and the mRNA is represented using a dotted line.

highlighted in recent studies. Cryo-EM structures of the exon junction complex (EJC)-UPF complex have positioned Upf1 on the $3^{\prime}$ side of the EJC (Melero et al. 2012), contradictory to the current notion of Upf1 localization at the $5^{\prime}$ side that is closer to the premature termination codon. It has also been reported that hUPF1 binds directly to mRNA, with binding varying as a function of mRNA $3^{\prime}$-UTR length (Hogg and Goff 2010; Kurosaki and Maquat 2013).

Rps26 is positioned on the solvent side of the 40 S platform and is a crucial component of the $40 \mathrm{~S}$ ribosome-binding site for mRNA (Ben-Shem et al. 2011; Sharifulin et al. 2012). Available structural data show that the binding site of eIF3 on the 40 S subunit overlaps with Rps26 as well as the other Upf1-interacting ribosomal proteins (Fig. 7). This observation is of interest because temperature-sensitive lesions in the Prt1 subunit of eIF3 (eIF3b) antagonize NMD in yeast (Welch and Jacobson 1999), and phosphorylated Upf1 interacts with eIF3 and inhibits translation initiation in mam- malian NMD (Isken and Maquat 2008). eIF3 has been implicated in efficient ribosome recycling after translation termination (Pisarev et al. 2007), and upfl $\Delta$ extracts have been shown to be defective in efficient ribosome recycling from a nonsense-containing mRNA (Ghosh et al. 2010). Collectively, these observations suggest a possible role for Upf1:eIF3 interaction in promoting ribosome dissociation and/or recycling from premature termination events.

\section{MATERIALS AND METHODS}

\section{Construction of yeast strains with epitope-tagged ribosomal proteins}

The chromosomal RPL25 and RPS13 genes were tagged with HA and c-Myc tags by homologous recombination at their $3^{\prime}$ ends using a single step PCR-mediated technique (Longtine et al. 1998). The oligonucleotide primers NA193 and NA194 were used for tagging RPL25 and oligonucleotide primers NA191 and NA192 were used for tagging RPS13 (Table 2).

\section{Plasmid construction}

His-tagged ribosomal fusion proteins were constructed by PCR amplification using oligonucleotides listed in Table 2 and yeast genomic DNA as template. The PCR products were digested with NdeI/ $B a m \mathrm{HI}$ and subcloned into the pET15b vector (Novagen).

\section{Affinity purification of ribosomes and western blot analysis}

Cell-free extracts were prepared as described previously (He et al. 2008). Extracts $\left(\begin{array}{ll}15 & A_{260}\end{array}\right)$ from cells expressing c-Myc tagged RPL25 or HA-tagged RPS13 were mixed with an equal volume of Buffer A (100 mM Tris- $\mathrm{HCl}, \mathrm{pH} 7.5,24 \mathrm{mM} \mathrm{Mg}(\mathrm{OAc})_{2}, 1 \mathrm{mM}$ dithiothreitol (DTT), $1 \mathrm{mM}$ PMSF, 50 units/mL RNasin [Roche]) and with $30 \mu \mathrm{L}$ of anti-HA or anti-c-MYC agarose slurry (Pierce). These mixtures were applied to spin columns, which were then incubated for $2 \mathrm{~h}$ at $4^{\circ} \mathrm{C}$ with gentle rocking. The columns were subjected to pulse centrifugation, and the respective flowthrough fractions were collected. The columns containing epitope-tagged ribosomal proteins were then washed three times with $0.8 \mathrm{~mL}$ Buffer W (100 mM Tris-HCl, pH 7.5, 24 mM Mg(OAc) 2 , 1 mM DTT, 100 $\mathrm{mM}$ PMSF, 50 units/mL RNAsin [Roche], protease inhibitor cocktail [Roche], $0.1 \% \mathrm{NP} 40$ ) and were eluted with $2 \times$ nonreducing sample buffer (Pierce) for $5 \mathrm{~min}$ at $100^{\circ} \mathrm{C}$ on a heat block. The eluted

TABLE 2. Oligonucleotides used in this study

NA191

NA192

NA193

NA194

Rps26 Forward

Rps26 Reverse
CTACGATGCTTTGGACATTGCTAACAGAATCGGTTACATTCGGATCCCCGGGTTAATTAA GAAAAATTTAAAAATAATATTAAATTTATTAATTAAACCAATTAGAGAATTCGAGCTCGTTTAAAC CCAAACTGGAAGTACGAATCCGCCACTGCCTCCGCTTTGGTCAACCGGATCCCCGGGTTAATTAA CAAAATATACATATAAAATAATGAAATAAATGATTTAAACACTGAATTCGAGCTCGTTTAAAC CCCGGCATATGCCAAAGAAGAAGCTTC CCCGGGGATCCTTATAAAGCCTTCTTG 
proteins were collected by pulse centrifugation, and $2 \mu \mathrm{L}$ of $\beta$-mercaptoethanol was added for SDS-PAGE analysis. For micrococcal nuclease treatment, 50 units of micrococcal nuclease (S7 nuclease, Roche) was preincubated with extract for $10 \mathrm{~min}$ at $25^{\circ} \mathrm{C}$ and digestion was then terminated by adding $100 \mathrm{mM}$ of ethylene glycol tetraacetic acid (EGTA). Puromycin ( $1 \mathrm{mM}$, Sigma) pretreatment of extracts was performed for $15 \mathrm{~min}$ at $4^{\circ} \mathrm{C}$ and $10 \mathrm{~min}$ at $37^{\circ} \mathrm{C}$. Aliquots of the initial extract as well as the supernatant and eluate of immunoprecipitations were subjected to SDS-PAGE analysis followed by western blotting using anti-Upfl (1:5000) (Belk et al. 1999), anti-c-Myc (1:5000, Sigma), or anti-HA (1:5000, Sigma) antibody.

\section{Purification of ribosomal subunits}

Cytoplasmic extracts were prepared as described previously with the omission of cycloheximide and inclusion of high salt $(0.5 \mathrm{M} \mathrm{KCl})$ (Mangus and Jacobson 1999). Extracts $\left(20 \mathrm{~A}_{260}\right)$ were centrifuged at $120,000 \mathrm{~g}$ for $10 \mathrm{~h}$ at $4^{\circ} \mathrm{C}$ on $34 \mathrm{~mL} 15 \%-40 \%$ sucrose gradients containing $10 \mathrm{mM}$ Tris- $\mathrm{HCl}, \mathrm{pH} 7.4,10 \mathrm{mM} \mathrm{MgCl}_{2}, 30 \mathrm{mM}$ $\mathrm{NH}_{4} \mathrm{Cl}$, and $1 \mathrm{mM} \mathrm{DTT}$. The gradients were scanned at $\mathrm{A}_{254}$, and the resulting absorbance profiles were used to determine the positions of the ribosomal fractions. Fractions corresponding to the $40 \mathrm{~S}$ and $60 \mathrm{~S}$ peaks were concentrated separately in Amicon Ultra15 100K NMWL filters (EMD Millipore). The concentrated samples were diluted with Buffer E (10 mM Tris- $\mathrm{HCl}, \mathrm{pH} 7.4,10 \mathrm{mM} \mathrm{KCl}$, $1 \mathrm{mM} \mathrm{MgCl}_{2}$ ) and reconcentrated as before. The subunits were aliquotted and stored at $-80^{\circ} \mathrm{C}$. Concentrations of $40 \mathrm{~S}$ and $60 \mathrm{~S}$ subunits were determined by spectrophotometry, using $1 \mathrm{~A}_{260}=50 \mathrm{nM}$ for $40 \mathrm{~S}$ and $1 \mathrm{~A}_{260}=25 \mathrm{nM}$ for $60 \mathrm{~S}$ subunits (Matasova et al. 1991). The integrity and the quality of purified $40 \mathrm{~S}$ and $60 \mathrm{~S}$ subunits were determined by SDS-PAGE analysis followed by western blotting using anti-Rps6 (1:5000, Cell Signaling) and analysis of rRNA on denaturing agarose gels.

\section{Yeast two-hybrid screening}

Full-length yeast UPF1 and mutant derivatives of the gene, all fused to the DNA binding domain of transcriptional activator GAL4 (He and Jacobson 1995; He et al. 1996), were used as bait against a twohybrid library of ribosomal proteins fused to the GAL4 activation domain (Valášek et al. 2003). The UPF1-GAL4 (DNA-binding domain) and RPS-GAL4 (activation domain) constructs were cotransformed into the two-hybrid tester strain GGY1::171 (Table 1). Transformants were incubated for $3-5 \mathrm{~d}$ at $30^{\circ} \mathrm{C}$ and qualitative and quantitative $\beta$-galactosidase activity was assayed as described previously (He et al. 1996).

\section{In vitro binding assay}

E. coli BL21 (DE3) cells (New England BioLabs, Inc.) were transformed with pET-His-Rps26, and protein expression was induced by addition of isopropyl-b-D-thiogalactopyranoside (IPTG) to a final concentration of $0.4 \mathrm{mM}$. Cells expressing the His-Rps 26 fusion protein were lysed in Talon Xtractor Buffer (Clontech Laboratories, Inc.). The lysate was centrifuged to remove cell debris, and the supernatant was incubated with purified yeast FLAG-Upfl for $1 \mathrm{~h}$ at $4^{\circ} \mathrm{C}$. Binding was followed by incubation with FLAG beads
(Sigma) for $4 \mathrm{~h}$ at $4^{\circ} \mathrm{C}$. After extensive washing in Talon Wash Buffer (Clontech Laboratories, Inc.), FLAG-Upf1 was eluted with 3XFLAG peptide and samples were analyzed on SDS-PAGE followed by western blotting using anti-His (1:7000; Maine Biotechnology) or anti-Upf1 (1:5000) antibody (Belk et al. 1999).

\section{ACKNOWLEDGMENTS}

We thank Alan Hinnebusch and Leoš Valášek for the 40S ribosomal protein cDNA two-hybrid library; Stephanie Kervestin for purified FLAG-Upf1; Stuart Peltz for several upf1 alleles; Shubhendu Ghosh for thoughtful discussions; and all the members of A.J.'s laboratory for technical help and for sharing materials and reagents. This work was supported by National Institutes of Health grant R37GM27757 to A.J.

Received March 29, 2013; accepted May 17, 2013.

\section{REFERENCES}

Algire MA, Maag D, Savio P, Acker MG, Tarun SZ Jr, Sachs AB, Asano K, Nielsen KH, Olsen DS, Phan L, et al. 2002. Development and characterization of a reconstituted yeast translation initiation system. RNA 8: 382-397.

Amrani N, Ganesan R, Kervestin S, Mangus DA, Ghosh S, Jacobson A. 2004. A faux $3^{\prime}$-UTR promotes aberrant termination and triggers nonsense-mediated mRNA decay. Nature 432: 112-118.

Amrani N, Dong S, He F, Ganesan R, Ghosh S, Kervestin S, Li C, Mangus DA, Spatrick P, Jacobson A. 2006. Aberrant termination triggers nonsense-mediated mRNA decay. Biochem Soc Trans 34: $39-42$.

Atkin AL, Altamura N, Leeds P, Culbertson MR. 1995. The majority of yeast UPF1 co-localizes with polyribosomes in the cytoplasm. Mol Biol Cell 6: 611-625.

Atkin AL, Schenkman LR, Eastham M, Dahlseid JN, Lelivelt MJ, Culbertson MR. 1997. Relationship between yeast polyribosomes and Upf proteins required for nonsense mRNA decay. J Biol Chem 272: $22163-22172$.

Azzam ME, Algranati ID. 1973. Mechanism of puromycin action: Fate of ribosomes after release of nascent protein chains from polysomes. Proc Natl Acad Sci 70: 3866-3869.

Bartel PL, Fields S. 1995. Analyzing protein-protein interactions using two-hybrid system. Methods Enzymol 254: 241-263.

Bartel P, Chien CT, Sternglanz R, Fields S. 1993. Elimination of false positives that arise in using the two-hybrid system. Biotechniques 14: 920-924.

Belgrader P, Cheng J, Maquat LE. 1993. Evidence to implicate translation by ribosomes in the mechanism by which nonsense codons reduce the nuclear level of human triosephosphate isomerase mRNA. Proc Natl Acad Sci 90: 482-486.

Belk JP, He F, Jacobson A. 1999. Overexpression of truncated Nmd3p inhibits protein synthesis in yeast. RNA 5: 1055-1070.

Ben-Shem A, Garreau de Loubresse N, Melnikov S, Jenner L, Yusupova G, Yusupov M. 2011. The structure of the eukaryotic ribosome at 3.0 \& resolution. Science 334: 1524-1529.

Bühler M, Steiner S, Mohn F, Paillusson A, Mühlemann O. 2006. EJCindependent degradation of nonsense immunoglobulin- $\mu$ mRNA depends on 3'-UTR length. Nat Struct Mol Biol 13: 462-464.

Chakrabarti S, Jayachandran U, Bonneau F, Fiorini F, Basquin C, Domcke S, Le Hir H, Conti E. 2011. Molecular mechanisms for the RNA-dependent ATPase activity of Upf1 and its regulation by Upf2. Mol Cell 41: 693-703.

Chamieh H, Ballut L, Bonneau F, Le Hir H. 2008. NMD factors UPF2 and UPF3 bridge UPF1 to the exon junction complex and stimulate its RNA helicase activity. Nat Struct Mol Biol 15: 85-93. 
Chan WK, Huang L, Gudikote JP, Chang YF, Imam JS, MacLean JA II, Wilkinson MF. 2007. An alternative branch of the nonsense-mediated decay pathway. EMBO J 26: 1820-1830.

Clerici M, Mourao A, Gutsche I, Gehring NH, Hentze MW, Kulozik A, Kadlec J, Sattler M, Cusack S. 2009. Unusual bipartite mode of interaction between the nonsense-mediated decay factors, UPF1 and UPF2. EMBO J 28: 2293-2306.

Czaplinski K, Ruiz-Echevarria MJ, Paushkin SV, Han X, Weng Y, Perlick HA, Dietz HC, Ter-Avanesyan MD, Peltz SW. 1998. The surveillance complex interacts with the translation release factors to enhance termination and degrade aberrant mRNAs. Genes Dev 12: $1665-1677$.

Fairman-Williams ME, Guenther UP, Jankowsky E. 2010. SF1 and SF2 helicases: Family matters. Curr Opin Struct Biol 20: 313-324.

Franks TM, Singh G, Lykke-Andersen J. 2010. Upf1 ATPase-dependent mRNP disassembly is required for completion of nonsense-mediated mRNA decay. Cell 143: 938-950.

Gaba A, Jacobson A, Sachs MS. 2005. Ribosome occupancy of the yeast CPA1 upstream open reading frame termination codon modulates nonsense-mediated mRNA decay. Mol Cell 20: 449-460.

Ghosh S, Ganesan R, Amrani N, Jacobson A. 2010. Translational competence of ribosomes released from a premature termination codon is modulated by NMD factors. RNA 16: 1832-1847.

Gozalbo D, Hohmann S. 1990. Nonsense suppressors partially revert the decrease of the mRNA level of a nonsense mutant allele in yeast. Curr Genet 17: 77-79.

He F, Jacobson A. 1995. Identification of a novel component of the nonsense-mediated mRNA decay pathway by use of an interacting protein screen. Genes Dev 9: 437-454.

He F, Brown AH, Jacobson A. 1996. Interaction between Nmd2p and Upf1p is required for activity but not for dominant-negative inhibition of the nonsense-mediated mRNA decay pathway in yeast. RNA 2: $153-170$

He F, Brown AH, Jacobson A. 1997. Upf1p, Nmd2p, and Upf3p are interacting components of the yeast nonsense-mediated mRNA decay pathway. Mol Cell Biol 17: 1580-1594.

He F, Li X, Spatrick P, Casillo R, Dong S, Jacobson A. 2003. Genomewide analysis of mRNAs regulated by the nonsense-mediated and $5^{\prime}$ to $3^{\prime}$ mRNA decay pathways in yeast. Mol Cell 12: 1439-1452.

He F, Amrani N, Johansson MJ, Jacobson A. 2008. Qualitative and quantitative assessment of the activity of the yeast nonsense-mediated mRNA decay pathway. Methods Enzymol 449: 127-147.

Hogg JR, Goff SP. 2010. Upf1 senses 3'UTR length to potentiate mRNA decay. Cell 143: 379-389.

Hu W, Petzold C, Coller J, Baker KE. 2010. Nonsense-mediated mRNA decapping occurs on polyribosomes in Saccharomyces cerevisiae. Nat Struct Mol Biol 17: 244-247.

Huang L, Lou CH, Chan W, Shum EY, Shao A, Stone E, Karam R, Song HW, Wilkinson MF. 2011. RNA homeostasis governed by cell type-specific and branched feedback loops acting on NMD. Mol Cell 43: 950-961.

Inada T, Winstall E, Tarun SZ Jr, Yates JR III, Schieltz D, Sachs AB. 2002. One-step affinity purification of the yeast ribosome and its associated proteins and mRNAs. RNA 8: 948-958.

Isken O, Maquat LE. 2008. The multiple lives of NMD factors: Balancing roles in gene and genome regulation. Nat Rev Genet 9: 699-712.

Ivanov PV, Gehring NH, Kunz JB, Hentze MW, Kulozik AE. 2008. Interactions between UPF1, eRFs, PABP and the exon junction complex suggest an integrated model for mammalian NMD pathways. EMBO J 27: 736-747.

Jacobson A, Izaurralde E. 2007. Nonsense-mediated mRNA decay: From yeast to metazoans. Chapter 23. In Translational control in biology and medicine, 659-691. Cold Spring Harbor Laboratory Press, Cold Spring Harbor, NY.

Johansson MJ, He F, Spatrick P, Li C, Jacobson A. 2007. Association of yeast Upflp with direct substrates of the NMD pathway. Proc Natl Acad Sci 104: 20872-20877.

Kashima I, Yamashita A, Izumi N, Kataoka N, Morishita R, Hoshino S, Ohno M, Dreyfuss G, Ohno S. 2006. Binding of a novel SMG-1-
Upf1-eRF1-eRF3 complex (SURF) to the exon junction complex triggers Upf1 phosphorylation and nonsense-mediated mRNA decay. Genes Dev 20: 355-367.

Kashima I, Jonas S, Jayachandran U, Buchwald G, Conti E, Lupas AN, Izaurralde E. 2010. SMG6 interacts with the exon junction complex via two conserved EJC-binding motifs (EBMs) required for nonsense-mediated mRNA decay. Genes Dev 24: 2440-2450.

Kervestin S, Jacobson A. 2012. NMD: A multifaceted response to premature translational termination. Nat Rev Mol Cell Biol 13: 700-712.

Kervestin S, Li C, Buckingham R, Jacobson A. 2012. Testing the fauxUTR model for NMD: Analysis of Upflp and Pablp competition for binding to eRF3/Sup35p. Biochimie 94: 1560-1571.

Kouba T, Dányi I, Gunišová S, Munzarová V, Vlčková V, Cuchalová L, Neueder A, Milkereit P, Valášek LS. 2012. Small ribosomal protein RPS0 stimulates translation initiation by mediating 40S-binding of eIF3 via its direct contact with the eIF3a/TIF32 subunit. PLoS One 7: e40464.

Kurosaki T, Maquat LE. 2013. Rules that govern UPF1 binding to mRNA 3' UTRs. Proc Natl Acad Sci 110: 3357-3362.

Lawford GR. 1969. The effect of incubation with puromycin on the dissociation of rat liver ribosomes into active subunits. Biochem Biophys Res Commun 37: 143-150.

Le Hir H, Moore MJ, Maquat LE. 2000. Pre-mRNA splicing alters mRNP composition: Evidence for stable association of proteins at exon-exon junctions. Genes Dev 14: 1098-1108.

Longtine MS, McKenzie A III, Demarini DJ, Shah NG, Wach A, Brachat A, Philippsen P, Pringle JR. 1998. Additional modules for versatile and economical PCR-based gene deletion and modification in Saccharomyces cerevisiae. Yeast 14: 953-961.

Losson R, Lacroute F. 1979. Interference of nonsense mutations with eukaryotic messenger RNA stability. Proc Natl Acad Sci 76: 5134-5137.

Maderazo AB, He F, Mangus DA, Jacobson A. 2000. Upf1p control of nonsense mRNA translation is regulated by Nmd2p and Upf3p. Mol Cell Biol 20: 4591-4603.

Mangus DA, Jacobson A. 1999. Linking mRNA turnover and translation: Assessing the polyribosomal association of mRNA decay factors and degradative intermediates. Methods 17: 28-37.

Matasova NB, Myltseva SV, Zenkova MA, Graifer DM, Vladimirov SN, Karpova GG. 1991. Isolation of ribosomal subunits containing intact rRNA from human placenta: Estimation of functional activity of $80 \mathrm{~S}$ ribosomes. Anal Biochem 198: 219-223.

Melero R, Buchwald G, Castaño R, Raabe M, Gil D, Lázaro M, Urlaub H, Conti E, Llorca O. 2012. The cryo-EM structure of the UPF-EJC complex shows UPF1 poised toward the RNA $3^{\prime}$ end. Nat Struct Mol Biol 19: 498-505, S491-S492.

Peltz SW, Brown AH, Jacobson A. 1993. mRNA destabilization triggered by premature translational termination depends on at least three cisacting sequence elements and one trans-acting factor. Genes Dev 7: 1737-1754.

Pisarev AV, Unbehaun A, Hellen CU, Pestova TV. 2007. Assembly and analysis of eukaryotic translation initiation complexes. Methods Enzymol 430: 147-177.

Sachs AB, Davis RW. 1989. The poly(A) binding protein is required for poly(A) shortening and $60 \mathrm{~S}$ ribosomal subunit-dependent translation initiation. Cell 58: 857-867.

Schoenberg DR, Maquat LE. 2012. Regulation of cytoplasmic mRNA decay. Nat Rev Genet 13: 246-259.

Serin G, Gersappe A, Black JD, Aronoff R, Maquat LE. 2001. Identification and characterization of human orthologues to Saccharomyces cerevisiae Upf2 protein and Upf3 protein (Caenorhabditis elegans SMG-4). Mol Cell Biol 21: 209-223.

Sharifulin D, Khairulina Y, Ivanov A, Meschaninova M, Ven'yaminova A, Graifer D, Karpova G. 2012. A central fragment of ribosomal protein S26 containing the eukaryote-specific motif YxxPKxYxK is a key component of the ribosomal binding site of mRNA region $5^{\prime}$ of the E site codon. Nucleic Acids Res 40: 3056-3065.

Sheth U, Parker R. 2006. Targeting of aberrant mRNAs to cytoplasmic processing bodies. Cell 125: 1095-1109. 
Singh G, Rebbapragada I, Lykke-Andersen J. 2008. A competition between stimulators and antagonists of Upf complex recruitment governs human nonsense-mediated mRNA decay. PLoS Biol 6: e111.

Spahn CM, Beckmann R, Eswar N, Penczek PA, Sali A, Blobel G, Frank J. 2001. Structure of the 80 S ribosome from Saccharomyces cerevisiae-tRNA-ribosome and subunit-subunit interactions. Cell 107: 373-386.

Sun X, Maquat LE. 2000. mRNA surveillance in mammalian cells: The relationship between introns and translation termination. RNA 6: $1-8$.

Valášek L, Mathew AA, Shin BS, Nielsen KH, Szamecz B, Hinnebusch AG. 2003. The yeast eIF3 subunits TIF32/a, NIP1/c, and
eIF5 make critical connections with the $40 \mathrm{~S}$ ribosome in vivo. Genes Dev 17: 786-799.

Wang W, Czaplinski K, Rao Y, Peltz SW. 2001. The role of Upf proteins in modulating the translation read-through of nonsense-containing transcripts. EMBO J 20: 880-890.

Welch EM, Jacobson A. 1999. An internal open reading frame triggers nonsense-mediated decay of the yeast SPT10 mRNA. EMBO J 18: 6134-6145.

Yamashita A, Izumi N, Kashima I, Ohnishi T, Saari B, Katsuhata Y, Muramatsu R, Morita T, Iwamatsu A, Hachiya T, et al. 2009. SMG-8 and SMG-9, two novel subunits of the SMG-1 complex, regulate remodeling of the mRNA surveillance complex during nonsense-mediated mRNA decay. Genes Dev 23: 1091-1105. 

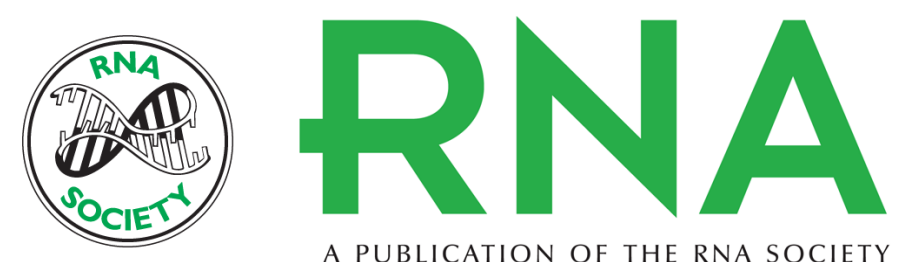

A PUBLICATION OF THE RNA SOCIETY

\section{Yeast Upf1 $\mathrm{CH}$ domain interacts with Rps26 of the $40 \mathrm{~S}$ ribosomal subunit}

Ei Ei Min, Bijoyita Roy, Nadia Amrani, et al.

RNA 2013 19: 1105-1115 originally published online June 25, 2013

Access the most recent version at doi:10.1261/rna.039396.113
References This article cites 62 articles, 26 of which can be accessed free at: http://rnajournal.cshlp.org/content/19/8/1105.full.html\#ref-list-1
Creative This article is distributed exclusively by the RNA Society for the first 12 months after the Commons full-issue publication date (see http://rnajournal.cshlp.org/site/misc/terms.xhtml). After 12 License months, it is available under a Creative Commons License (Attribution-NonCommercial 3.0 Unported), as described at http://creativecommons.org/licenses/by-nc/3.0/.

Email Alerting Receive free email alerts when new articles cite this article - sign up in the box at the Service top right corner of the article or click here.

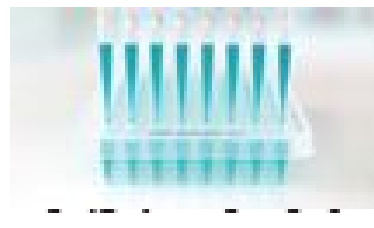

\section{Providing Precise Solutions for} your research.

To subscribe to RNA go to:

http://rnajournal.cshlp.org/subscriptions 